\title{
JURIANAI
}

Jurnal Pendidikan Ekonomi

$\therefore$ JUR KAIMI

VOLLME

5
NOMOR

2

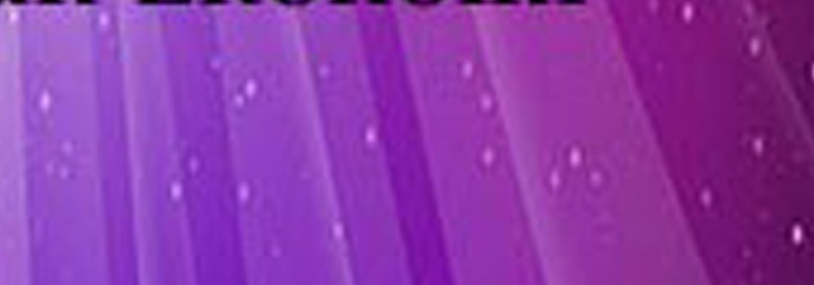




\title{
JURKAMI: Jurnal Pendidikan Ekonomi \\ http://jurnal.stkippersada.ac.id/jurnal/index.php/JPE \\ JURKAMI Volume 5, no 2, 2020
}

\section{PENGARUH PERSONAL SELLING DAN ADVERTISING TERHADAP PENJUALAN POLIS ASURANSI PADA PT JASA RAHARJA PUTERA CABANG MATARAM}

\author{
Abdul Basit ${ }^{1}$, Ika Nirmala Fulvia ${ }^{2}$ \\ Universitas Islam Negeri (UIN) Sunan Kalijaga Yogyakarta, Indonesia \\ Email: abdbasit688@gmail.com, malafulfia@gmail.com
}

Diterima: 7 Oktober 2020; Disetujui: 27 Oktober 2020; Diterbitkan: 1 November 2020

Abstract: This study was conducted to determine the effect of personal selling $d$ an a dvertising against the sale of insurance policies either Prado or simultaneously, and how is the level of influence of personal selling and advertising PT Jasaraharja Puera Branch Mataram. A population of 2,625 customers, the sample using random sampling samples taken as much as $10 \%$ of the population from the calculation using the Solvin formula obtained a sample of 97 customers. This type of research uses quantitative research with a causal associative research approach by using questionnaires which are considered in accordance with the research carried out which aims to determine the causal relationship between the independent variables (variables that affect the dependent variable). In this study using validity and reliability and using data analysis techniques, namely classical assumption test, hypothesis test, linear regression analysis with the help of SPSS 16 software

\section{Keywords: Personal Selling, Advertising and Insurance Policy Sales}

Abstrak: Penelitian ini dilakukan untuk mengetahui pengaruh personal selling dan advertising terhadap penjualan polis asuransi baik secara persal maupun simultan, dan bagaimanakan tingkat pengaruh personal selling dan advertising pada PT Jasaraharja Puera Cabang Mataram. Populasi sebanyak 2.625 nasabah, sampelnya menggunakan sample random sampling yang diambil sebanyak $10 \%$ dari populasi dari perhitungan menggunakan rumus solvin diperoleh hasil sampel sebanyak 97 nasabah. Jenis penelitian ini menggunakan penelitian kuantitatif dengan pendekatan penelitian asosiatif kausal dengan menggunakan penyebaran kuesioner yang dianggap sesuai dengan penelitian yang dilakukan yang bertujuan untuk mengetahui hubungan yang bersifat sebab akibat antara variabel independen (variabel yang mempengaruhi dengan variabel dependen (variabel yang dipengaruhi). Dalam penelitian ini menggunakan validitas dan reliabilias serta menggunakan teknik analisis data yaitu uji asumsi klasik, uji hipotesis, analisis regresi linier dengan bantuan software SPSS 16.

Kata Kunci: Personal Selling, Advertising dan Penjualan Polis Asuransi 


\section{PENDAHULUAN}

Asuransi merupakan kegiatan usaha yang bergerak di bidang usaha asuransi, yaitu jasa keuangan yang menghimpun dana masyarakat melalui pengumpulan dana masyarakat melalui pengumpulan premi asuransi memberikan perlindungan kepada anggota masyarakat pemakai jasa asuransi terhadap kemungkinan timbul kerugian karena suatu pristiwa yang tidak pasti atau terhadap hidup atau meninggalnya seseorang. Perusahaan perasuransian hanya dapat didirikan oleh warga negara Indonesia dan atau badan hukum Indonesia yang sepenuhnya dimiliki warga negara Indonesia dan atau badan hukum Indonesia.(Darmawi, 2004).

Asuransi merupakan perjanjian antara dua pihak atau lebih yang pihak penanggung mengikat diri kepada tertanggung dengan menerima premi asuansi untuk memberikan penggantian kepada tertanggung karena krugian, kerusakan atau tanggung atau kehilangan keuntungan yang diharapkan, atau tanggung jawab hukum kepada pihak ketiga yang mungkin akan diderita tertanggung.Secara historis, kajian tentang pertanggungan telah dikenal sejak zaman dahulu dan telah dipraktekkan di tengahtengah masyarakat walaupun dalam bentuk yang sangat sederhana. Ini dikarenakan nilai dasar penopang dari konsep "pertanggungan yang terwujud dalam bentuk tolong-menolong sudah ada bersama dengan adanya manusia.

Di tengah persaingan yang semakin ketat tersebut, pemasar juga menghadapi berbagai keputusan sulit dan berat. Mereka harus menentukan mutu dan keistimewaan produk, menetapkan pelayanan yang diperlukan, menetapkan harga, menentukan saluran distribusi, memutuskan berapa uang yang akan dikeluarkan untuk pemasaran, dan memutuskan bagaimana cara membagi sumber daya mereka untuk periklanan, target penjualan, tenaga penjualan, dan alat-alat pemasaran lainnya.Terdapat dua unsur yang berperan penting dalam aktivitas penjualan yaitu personal selling dan advertising. Personal Selling adalah interaksi antar individu, saling bertemu muka yang ditujukan untuk menciptakan, memperbaiki, menguasai atau mempertahankan hubungan pertukaran yang saling menguntungakan dengan pihak lain. Penjualan berperan sebagai jembatan utama, penghubung antara perusahaan sebagai produsen dengan para pelanggan sebagai konsumen. Cara untuk mendapatkan penjualan adalah dengan melakukan optimalisasi disetiap sektor penjualan atau pemasaran produk/jasa yang dihasilkan oleh perusahaan kepada konsumen, salah satunya adalah melalui personal selling, yaitu strategi penjualan produk/jasa yang dilakukan secara 
langsung oleh penjual secara aktif kepada konsumen melalui pendekatan komunikasipersonal. (Hermawan, 2012).

Strategi penjualan seperti ini adalah strategi penjualan klasik yang memiliki prinsip-prinsip tersendiri yang harus dikuasai oleh sales persons, di antaranya tiga aspek penting, yaitu profesionalisme (sales profesionalisme), memiliki kekuatan untuk negosiasi (negotiation), dan upaya untuk menjalin hubungan dengan konsumen (relationship marketing), baik sebelum membeli produk maupun sesudah membeli produk.(Philip, 2001)

Berkenaan dengan personal selling setiap perusahaan haruslah mengatur penyampaian personal selling sebaik mungkin terhadap penjualan khususnya pada perusahaan asuransi pada PT Jasaraharja Putera Mataram. PT Jasaraharja Putera adalah salah satu perusahaan BUMN asuransi yang cukup terkemuka di Indonesia dibandingkan dengan perusahan asuransi lainnya. Selain pelayanannya yang memuaskan perusahaan ini juga melayani beberapa jenis asuransi. Advertising juga merupakan hal penting dalam proses penjualan polis yang berarti advertising adalah merupakan suatu proses komunikasi yang bertujuan untuk membujuk. (Durianto, 2003)

Tujuan advertising adalah periklanan menjalankan sebuah fungsi informasi biasanya dilakukan secara besar- besaran pada tahap awal suatu jenis produk, tujuannya untuk membentuk permintaan pertama, periklanan menjalankan sebuah fungsi persuasive penting dilakukan dalam tahap kompetitif, tujuannya untuk membentuk permintaan selektif untuk suatu merk tertentu, periklanan menjalankan sebuah fungsi pengingat iklan pengingat sangat penting bagi produk yang sudah mapan, bentuk iklan yang berhubungan dengan iklan ini adalah iklan penguat (Inforcement advertising) yang bertujuan meyakinkan pembeli sekarang bahwa mereka telah melakukan pilihan yangbenar. Sementara itu mereka harus juga mempertahankan diri agar tetap hidup di tengah persaingan, berbagai upaya mereka lakukan, salah satunya yaitu dengan cara meningkatkan volume penjualan perusahaan semaksimal mungkin. Namun ini juga bukan perkara yang mudah, pesaing berdatangan bukan hanya dari dalam negeri namun juga dari luar negeri karena jarak tidak lagi masalah sejak zaman berubah menjadi serba canggih dan modern. Terlepas dari hal-hal tersebut, pada kenyataannya masih ada hal-hal yang menghambat penjualan polis asuransi diantaranya yaitu volume penjualan lebih rendah dari biaya yang dikeluarkan perusahaan, kurangnya kepercayaan nasabah tentang polis asuransi tersebut. Hal ini diduga ada kaitannya dengan unsur personal selling 
dan advertising yang telah dijelaskansebelumnya Dimana kedua hal tersebut mempengaruhi penjualan dalam PT Jasaraharja Putera Mataram

\section{KAJIAN TEORI}

Restu Stiawan, yang berjudul "Pengaruh Brand Image dan Promosi Terhadap Keputusan Nasabah Memilih Produk Asuransi Syariah"2017.Hasil penelitian pada taraf signifikan 5\% menunjukkkan bahwa brand image berpengaruh positif signifikan terhadap keputusa pembelian produk. Hal ini dibuktikan dengan nilai $\mathrm{t}$ hitung lebih besar dari t tabel 4,252 > I,984. Promosi berpengaruh positif dan signifikan terhadap keputusan pembelian produk, hal ini dibuktikan dengan dengan nilait hitung lebih besar dari t tabel 6,496>1,984, brand image dan promosi bersama-sama berpengaruh positif dan signifikan terhadap keputusan pembelian produk. Hal ini dibuktikan dengan nilai $\mathrm{t}$ hitung lebih besar dari t tabel 345,357>3,942 artinya semakin baik brand dan promosi maka dapat meningkatkan keputusan pembelian produk

Ida Royani Tamba, yang berjudul "Pengaruh Personal Selling dan Kualitas Pelayanan Terhadap Keputusan Pembelian Polis Asuransi Jiwa PT.Asuransi Jiwasaya (Persero) Cabang Pekanbaru'2015.

Dari hasil analisis data meliputi uji validias, reliabilitas, dan uji regresi liner berganda hasil penelitian menunjukkan bahwa personal selling tidak berpengaruh signifikan pada keputusan pembelia dengan $\mathrm{t}$ hitung 5.506 $>\mathrm{t}$ tabel 1.985 . variabel kualitas pelayanan mempunyai pengaruh terhadap keputusan pembelian dengan nilai t hitung 3,317 > t tabel 1.985 dan berdasarkan uji secara simultan menyimpulkan bahwa personal selling dan kualitas pelayanan secara bersama-sama memiliki pengaruh terhadap keputusan pembelian polis asuransi jiwa PT Asuransi Jiwasaya (Persero) Cabang Pekanbaru.

\section{METODOLOGI PENELITIAN}

Penelitian ini menggunakan metode penelitian kuantitatif karena data penelitiannya berupa angka-angka dan dianalisis menggunakan yang kongkrit, obyektif, terukur, rasional, dan sistematis. Metode kuantitatif dapat diartikan sebagai metode penelitian yang berlandaskan pada filsafat positivisme, digunakan untuk meneliti pada populasi atau sampel tertentu, pengumpulan data menggunakan instrumen penelitian, analisis data bersifat kuantitatif / statistik, dengan tujuan untuk menguji hipotesis yang telahditetapkan. pendekatan penelitian ini adalah pendekatan asosiatif.Dengan penelitian ini maka akan dapat dibangun suatu teori yang dapat berfungsi untuk menjelaskan, meramalkan dan mengontrol suatu gejala, ataupun juga hubungan yang bersifat sebab 
akibat antara variabel independen (variabelyang mempengaruhi) dengan variabel dependen (variabel yang dipengaruhi).Artinya keadaan satu variabel disebabkan, ditentukan, dan dipengaruhi oleh satu atau lebih variabel lain. Yaitu hubungan antara Personal Selling $\left(\mathrm{X}_{1}\right)$ Advertising $\left(\mathrm{X}_{2}\right)$ terhadap Penjualan $(\mathrm{Y})$. Dalam penelitian ini menggunakan validitas dan reliabilias serta menggunakan teknik analisis data yaitu uji asumsi klasik, uji hipotesis, analisis regresi linier.

Dalam penelitian ini, besarnya jumlah sampel yang diambil memakai rumus Slovin

$$
n=\frac{N}{1+N e^{2}}
$$

Keterangan:

$N=$ jumlah populasi

$\mathrm{n}=$ jumlah sampel

$\mathrm{e}=$ Persen kelonggaran ketidak telitian

karena kesalahan pengambilan

\section{HASIL DAN PEMBAHASAN}

Karakteristik responden berdasarkan data hasil kuesioner yang telah terkumpul, selanjutnya peneliti melakukan analisis data yang didasarkan pada hasil perhitungan secara kuantitatif yang berguna untuk pembahasan rumusan masalah penelitian dan juga mengungkap kecenderungan respoden terkait dengan Pengaruh Personal Selling dan Advertising
Terhadap Penjualan Polis Asuransi Pada PT Jasaraharja Putera Cabang Mataram.

Berdasarkan penyebaran kuesioner sebanyak 97 angket, selanjutnya dari data tersebut diberikan informasi tentang karakteristik atau identitas responden yang terdiri dari tingkatan usia, jenis kelamin, dan pekerjaan responden. Hal ini dilakukan dengan harapan bahwa ini dapat menjadi masukan terkait dengan Personal Selling dan Advertising Terhadap Penjualan Polis Asuransi Pada PT Jasaraharja Putera Cabang Mataram.

Dari hasil penyebaran kuesioner berdasarkan tingkatan usia Dewasa diperoleh data 55 orang atau $57 \%$ responden. Dan tingkatan usia remaja diperoleh 36 orang, atau $37 \%$ responden. Dan yang terakhir untuk tingkatan usia anak-anak diperoleh 6 orang atau $6 \%$ responden dari total 97 responden.

Berdasarkan klasifikasi pekerjaanpekerjaan diperoleh data pekerjaan responden pegawai diperoleh 50 orang atau $51,5 \%$, wiraswasta diperoleh 12 orang atau $12,3 \%$, pensiunan diperoleh 6 .

Klasifikasi responden berdasarkan jenis kelamin diperoleh data untuk yang berjenis kelamin perempuan sebanyak 46 orang responden atau 47,5\% dari total 97 responden, sedangkan untuk yang berjenis kelamin laki-laki 51 orang responden atau $52,5 \%$ dari total 97 responden. 
Dari hasil penyebaran kuesioner berdasarkan tingkatan usia Dewasa diperoleh data 55 orang atau $57 \%$ responden. Dan tingkatan usia remaja diperoleh 36 orang, atau $37 \%$ responden. Dan yang terakhir untuk tingkatan usia anak-anak diperoleh 6 orang atau $6 \%$ responden dari total 97 responden

Uji reliabilitas digunakan untuk mengukur suatu kuesioner yang merupakan indikator dari variabel. Suatu kuesioner dikatakan reliabel jika jawaban konsisten dari waktu kewaktu. Berdasarkan tabel hasil uji reliabilitas Personal Selling (X1) di bawah, memiliki nilai Cronbach Alpha sebesar 0,660 yang lebih besar dari 0,60. Bersadarkan ketentuan di atas maka dalam penelitian ini dikatakan reliabel

Tabel 2: Hasil Uji Reliabiltas Personal Selling Reliability Statistics

\begin{tabular}{ccc}
\hline $\begin{array}{c}\text { Cronbach's } \\
\text { Alpha }\end{array}$ & $\begin{array}{c}\text { Cronbach's Alpha } \\
\text { Based } \\
\text { On Standardized Items }\end{array}$ & $\begin{array}{c}\mathrm{N} \\
\text { of } \\
\text { Items }\end{array}$ \\
\hline .660 & .658 & 6 \\
\hline
\end{tabular}

Berdasarkan tabel hasil uji reliabilitas Personal Selling $\left(\mathrm{X}_{1}\right)$ di atas, memiliki nilai Cronbach Alpha sebesar 0,660 yang lebih besar dari 0,60. Bersadarkan ketentuan di atas maka dalam penelitian ini dikatakan reliabel
Tabel 3: Uji Reliabilitas Advertising Reliability Statistics

\begin{tabular}{|c|c|c|}
\hline $\begin{array}{c}\text { Cronbach's } \\
\text { Alpha }\end{array}$ & $\begin{array}{c}\text { Cronbach's Alpha } \\
\text { Based } \\
\text { On Standardized } \\
\text { Items }\end{array}$ & $\begin{array}{c}\mathrm{N} \\
\text { Of } \\
\text { Items }\end{array}$ \\
\hline .758 & .763 & 6 \\
\hline
\end{tabular}

Berdasarkan tabel hasil uji reliabilitas Advertising $\left(\mathrm{X}_{2}\right)$ di atas, memiliki nilai Cronbach Alpha sebesar 0,758 yang lebih besar dari 0,60. Bersadarkan ketentuan di atas maka dalam penelitian ini dikatakan reliabel

Table 4: Uji Reliabilitas Penjualan Reliability Statistics

\begin{tabular}{|c|c|c|}
\hline $\begin{array}{c}\text { Cronbach's } \\
\text { Alpha }\end{array}$ & $\begin{array}{c}\text { Cronbach's Alpha } \\
\text { Based } \\
\text { On Standardized } \\
\text { Items }\end{array}$ & $\begin{array}{c}\text { N Of } \\
\text { Items }\end{array}$ \\
\hline .731 & .771 & 10 \\
\hline
\end{tabular}

Berdasarkan tabel hasil uji reliabilitas Penjualan (Y) di atas, memiliki nilai Cronbach Alpha sebesar 0,731 yang lebih besar dari 0,60. Bersadarkan ketentuan di atas maka dalam penelitian ini dikatakan reliable. Dari keterangan tabel di atas dapat diketahui bahwa masing-masing variabel memiliki cronbach alpha > 0,60. Dengan demikian variabel X1,X2 dan Y dapat dikatakan reliabel dan dapat dilanjutkan ke tahap selanjutnya

Tahap berikutnya yaitu Uji Asumsi Klasik. Berdasarkan Uji multikolinieritas dilakukan untuk menguji apakah ada model regresi ditemukan adanya korelasi 
antar variabel bebas. Model regresi yang baik adalah non multikolinieritas. Analisis ini ditentukan oleh besarnya nilai tolerance dan VIF (varians inflation factor). Pedoman suatu model regresi yang bebas multikolinieritas adalah jika nilai tolerance lebih besar dari 0,10 dan nilai VIF lebih kecil dari 10,00 maka artinya tidak terjadi Multikoloniaritas dalam model regresi. Berdasarkan hasil pengolahan $\quad$ SPSS 16.0 forWindowsdidapatkan nilai VIF (varians inflation factor) dan tolerance untuk masing-masing variabel bebas pada tabel berikut ini:

Tabel 5: Uji Multikolinieritas Coefficients ${ }^{\mathrm{a}}$

\begin{tabular}{|c|c|c|c|c|c|c|c|}
\hline \multirow{2}{*}{ Model } & \multicolumn{2}{|c|}{$\begin{array}{c}\text { Unstandardized } \\
\text { Coefficients }\end{array}$} & \multirow{2}{*}{$\begin{array}{l}\begin{array}{c}\text { Standardized } \\
\text { Coefficients }\end{array} \\
\text { Beta }\end{array}$} & \multirow[t]{2}{*}{$\mathrm{T}$} & \multirow{2}{*}{ Sig. } & \multicolumn{2}{|c|}{$\begin{array}{c}\text { Collinearity } \\
\text { Statistics }\end{array}$} \\
\hline & $\mathrm{B}$ & Std. Error & & & & Tolerance & VIF \\
\hline 1 (Constant) & 17.476 & 4.688 & & 3.727 & .000 & & \\
\hline $\begin{array}{l}\text { Personal } \\
\text { Selling }\end{array}$ & .931 & .143 & .561 & 6.523 & .000 & .987 & 1.013 \\
\hline Advertising & -.026 & .133 & -.017 & -.194 & .847 & .987 & 1.013 \\
\hline
\end{tabular}

Berdasarkan tabel diatas dapat diketahui bahwa besarnya nilai Tolerance sebesar 0,987 lebih besar dari 0,10 dan nilai VIF sebesar 1,013 lebih lebih kecil dari 10.00, jadi kesimpulan dalam uji ini tidak terjadi Multikoloniaritas dalam model regresi.

Uji normalitas bertujuan untuk menguji apakah dalam model regresi variabel terikat dan variabel bebas keduanya mempunyai distribusi normal atau tidak. Jika signifikannya >0,05 maka berdistribusi normal dan sebaliknyajika signifikan $<0,05$ maka variabel tidak berdistribusi normal, danJika pada grafik tersebut penyebaran datanya mengikuti pola garis lurus, maka grafik tersebut normal. Berikut tabel dan grafik hasil uji spss:

\section{Tabel 6: Uji Normalitas}

One-Sample Kolmogorov-Smirnov Test

\begin{tabular}{lc}
\hline & $\begin{array}{c}\text { Unstandardized } \\
\text { Residual }\end{array}$ \\
\hline $\mathrm{N}$ & 97 \\
\hline Normal Mean & .0000000 \\
\hline $\begin{array}{l}\text { Parametersa Std. } \\
\text { Deviation }\end{array}$ & 3.01570107 \\
\hline Most Absolute & .072 \\
\hline \begin{tabular}{l} 
Extreme \\
\multicolumn{1}{c}{ Positive }
\end{tabular} \\
$\begin{array}{l}\text { Differences Negative } \\
\text { Kolmogorov-Smirnov } \\
\text { Z }\end{array}$ \\
\hline Asymp. Sig. (2-tailed) \\
\hline
\end{tabular}


Dari hasil uji normalitas metode Kolomogrov Smirnov didapatkan hasil signifikansi dari uji normalitas sebesar 0,696 dimana hasil tersebut $>0,05$. Sehingga dapat disimpulkan bahwa uji normalitas pada penelitian ini adalah terdistribusi normal

Normal P-P PIot of Regression Standardized Residual

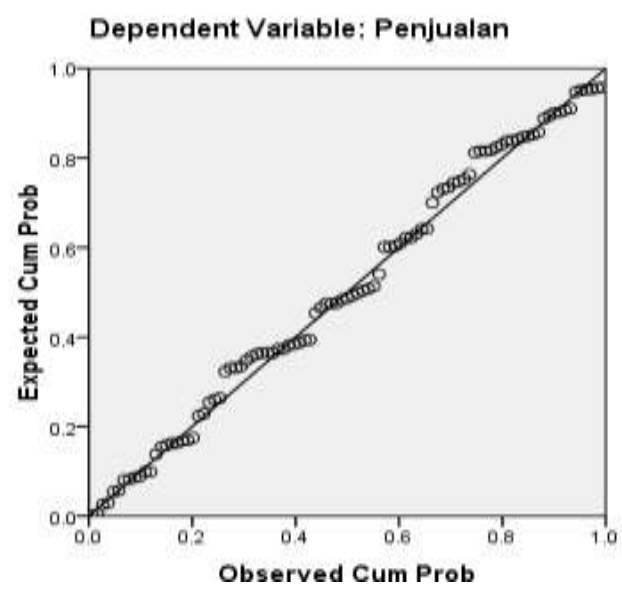

Gambar 1

Uji Normalitas P Plot

Dari hasil uji normal probability plot menunjukkan bahwa data menyebar di sekitar garis diagonal dan mengikuti arah garis diagonal.Jadi kesimpulannya melalui dua uji dengan spss uji normalitas berdistribusi normal.

Uji Heteroskedastisitas

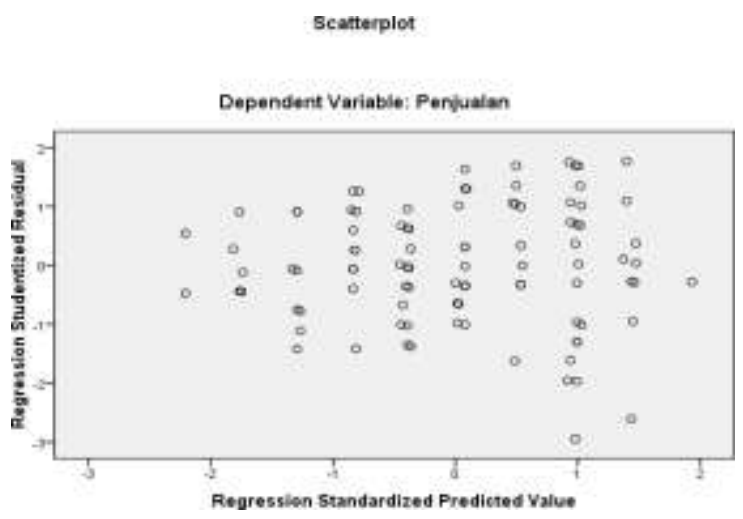

Gambar 2

Uji Heteroskedastisitas

Scatterplot tersebut menunjukan titik-titik data menyebar di atas dan dibawah atau disekitar angka 0 , titiik-titik tidak menggumpal hanya di bawah dan diatas saja, penyebaran tiitik- titik tidak membentuk pola bergelombang melebar kemudian menyempit dan melebar kembali. dari hasil uji heteroskedastisitas menggunkan metode scatterplot tidak terjadi heteroskedastisitas.

Tabel 7: Uji t

\begin{tabular}{lccccc}
\hline & \multicolumn{2}{c}{$\begin{array}{c}\text { Unstandardized } \\
\text { Coefficients }\end{array}$} & $\begin{array}{c}\text { Standardized } \\
\text { Coefficients }\end{array}$ & & \\
\cline { 2 - 4 } Model & $\mathrm{B}$ & Std. Error & Beta & T & Sig. \\
\hline 1 (Constant) & 17.476 & 4.688 & & 3.727 & .000 \\
\hline $\mathrm{x} 1$ & .931 & .143 & .561 & 6.523 & .000 \\
\hline $\mathrm{x} 2$ & -.026 & .133 & -.017 & -.194 & .847 \\
\hline
\end{tabular}

Dari hasi pengujian hipotesis (H1.1) yang dilakukan peneliti terbukti bahwa personal selling memiliki pengaruh positif yang signifikan terhadap penjualan polis asuransi pada PT Jasaraharja Putera Cabang Mataram. Melalui hasil perhitungan yang diperoleh nilai thitung sebesar 6.523 oleh karena itu nilai tersebut 
lebih besar dari $t_{\text {tabel }} 1.9855$,berarti personal selling berpengaruh terhadap penjualan polis asuransi pada PT Jasaraharja Putera Cabang Mataram.

Dari hasil pengujian hipotesis (H1.2) yang dilakukan peneliti terbukti bahwa advertising tidak mempengaruhi terhadap penjualan polis asuransi pada PT Jasaraharja Putera Cabang Mataram. Melalui hasil perhitungan yang telah dilakukan diperoleh nilai $t_{\text {hitung }}$ sebesar 0,194 oleh karena itu nilai tersebut lebih kecil dari $\mathrm{t}_{\text {tabel }} 1,9855$, berarti advertising tidak berpengaruh terhadap penjualan polis asuransi pada PT Jasaraharja Putera Cabang Mataram.

Dari hasil pengujian Hipotesis Ketiga (H1.3) didapat nilai $F_{\text {hitung }} 21.420$ dengan tingkat signifikansi 0,000 yang menunjukkan angka dibawah 0,5, sehingga dapat disimpulkan bahwa terdapat pengaruh secara bersama-sama variabel independen (Personal selling dan advertising) terhadap variabel dependen (Penjualan polis asuransi) pada PT Jasaraharja Putera Cabang Mataram

\begin{tabular}{lccccc}
\hline Model & $\begin{array}{c}\text { Sum of } \\
\text { Squares }\end{array}$ & Df & Mean Square & F & Sig. \\
\hline 1 Regression & 397.902 & 2 & 198.951 & 21.420 & $.000^{\text {a }}$ \\
Residual & 873.067 & 94 & 9.288 & & \\
\hline Total & 1270.969 & 96 & & & \\
\hline
\end{tabular}

Berdasarkan tabel di atas diketahui nilai Sig. untuk pengaruh X1 dan X2 secara simultan terhadap Y sebesar 0,000 $<0,05$ dan nilai fhitung $21.420>$ ftabel 3.09. disimpulkan bahwa H3 diterima yang berarti terdapat pengaruh $\mathrm{X} 1$ dan X2 secara simultan terhadapY

Tabel 9: Uji koefisien determinasi

\begin{tabular}{|c|c|c|c|c|}
\hline Model & $\mathrm{R}$ & $\begin{array}{c}\mathrm{R} \\
\text { Square }\end{array}$ & $\begin{array}{c}\text { Adjusted } \\
\text { R } \\
\text { Square }\end{array}$ & $\begin{array}{c}\text { Std. } \\
\text { Error Of } \\
\text { The } \\
\text { Estimate }\end{array}$ \\
\hline
\end{tabular}

$\begin{array}{lllll}1 & .560 \mathrm{a} & .313 & .298 & 3.04761\end{array}$

Predictors: (Constant),x2,x1

Berdasarkan tabel di atas diketahui nilai R Square sebesar 0,313 , hal ini berarti mengandung arti bahwa pengaruh variabel $\mathrm{X}_{1}$ dan $\mathrm{X}_{2}$ secara simultan terhadap variabel $\mathrm{Y}$ adalah sebesar 31,3\%.

Analisis Regesi Linier Berganda Suatu model persamaan regresi linier berganda digunakan untuk menjelaskan hubungan antara satu variabel dependen dengan lebih dari satu variabel independen. Dalam penelitian ini model persamaan regresi linier ganda yang disusun untuk mengetahui pengaruh antara Personal Selling dan Advertising (sebagai variabel independen) terhadap keputusan Penjualan (sebagai variabel dependen) secara bersama-sama adalah $\mathrm{Y}=\mathrm{a}+\mathrm{b} 1 \mathrm{X}_{1}$ 
+ b2 $\mathrm{X}_{2}$. Hasil analisis data dengan versi 16.0 diperoleh perhitungan sebagai menggunakan program SPSS for windows berikut:

Tabel 10 Uji Regresi Linier Berganda Coefficientsa

\begin{tabular}{cccccc}
\hline \multirow{2}{*}{ Model } & \multicolumn{2}{c}{ Unstandardized Coefficients } & $\begin{array}{c}\text { Standardized } \\
\text { Coefficients }\end{array}$ & $\mathrm{T}$ & Sig. \\
\cline { 2 - 5 } & $\mathrm{B}$ & Std. Error & Beta & & \\
\hline 1 (Constant) & 17.476 & 4.688 & & 3.727 & .000 \\
\hline $\mathrm{x} 1$ & .931 & .143 & .561 & 6.523 & .000 \\
\hline $\mathrm{x} 2$ & -.026 & .133 & -.017 & -.194 & .847 \\
\hline
\end{tabular}

Berdasarkan hasil analisis regresi linear berganda pada tabel di atas di peroleh persamaan regresi yakni $\mathrm{Y}=\mathrm{a}+\mathrm{b}$ $\mathrm{X} 1+\mathrm{b} 2 \mathrm{X} 2=17.476+931+-.026$.

Dari persamaan regresi linier berganda di atas dapat diartikan dan di ambil keputusan sebagai berikut : Nilai konstan (Y) sebesar 17.478 artinya jika variabel Personal Selling (X1) dan vari tidak dimasukkan dalam penelitian, maka variabel keputusan pembelian meningkat sebesar 17.476 .

Koefisien regresi $\mathrm{X}_{1}$ (Personal Selling) sebesar 0,931 atau $0,959 \%$ dapat disimpulkan bahwa variabel Personal Seling mempunyai pengaruh positif tehadap panjualan polis asuransi pada PT Jasaraharja Putera Cabang Mataram. Jika variabel Personal Selling $\left(\mathrm{X}_{1}\right)$ di tingkatkan $1 \%$ maka penjualan polis asuransi (Y) meningkat sebesar 0,959\%. Dengan asumsi variabel lain dianggap konstant. Hal ini menyatakan bahwa adanya Personal Selling dalam sebuah produk barang maka keputusan pembelian akan meningkat

Koefisien regresi $\mathrm{X}_{2}$ (Advertising) sebesar -026 dapat disimpulkan bahwa variabel Advertising tidak mempengaruhi terhadap penjualan polis asuransi pada PT Jasaraharja Putera Cabang Mataram

\section{Pembahasan}

Berdasarkan hasil uji hipotesis yang telah dilakukan diketahui bahwa personal selling berpengaruh terhadap penjualan polis asuransi pada PT Jasaraharja Putera Cabang Mataram diketahui nilai sig. untuk pengaruh personal selling untu ppenjualan sebesar $0,000<0,05$ dan nilai thitung $6.523>$ ttabel 1.9855, bahwa dapat disimpulkan personal selling dapat diterima yang berarti berpengaruh pada penjualan, sedangkan advertising nilai sig. $0,847>0,05$ dan nilai thitung $-0,194<$ 1,9855, sehingga dapat disimpulkan bahwa advertising ditolak yang berarti tidak berpengaruh terhadap penjualan polis asuransi. Berdasarkan hasil uji hipotesis uji f diketahui nilai sig. untuk pengaruh 
personal selling dan advertising secara simultan terhadap penjualan polis asuransi sebesar $0,000<0,05$ dan nilai fhitung $21.420>3.09$, sehingga dapat disimpulkan bahwa personal selling dan advertising secara simultan diterima yang berarti terdapat pengaruh terhadap penjualan polis asuransi pada PT Jasaraharja Putera Cabang Mataram.

Sementara itu hasil penelitian dari Zuriatin (2016) menunjukkan bahwa personal selling, direct selling dan hubungan masyarakat secara bersamasama berpengaruh signifikan terhadap kepuasan nasabah dengan nilai sig. 0,000. Variabel direct selling mempunyai pengaruh positif dan tidak signifikan terhadap kepuasan nasabah BMT UGT Sidogiri KCP Kanigoro Blitar dengan nilai sig. 0,423 dan variabel hubungan masyarakat mempunyai pengaruh positif dan tidak signifikan terhadap kepuasan nasabah BMT UGT Sidogiri KCP Kanigoro Bllitar dengan nilai sig. 0,247. nilai $\mathrm{r}$ hitung pada kolom corrected itemtotal correlation untuk masing-masing item memiliki $r$ hitung lebih besar dan positif dibandingkan $r$ tabel untuk $\mathrm{df}=97$ $2=95$ dan alpha 5\%. Dengan uji satu sisi didapat $r$ tabel sebesar 0,1996, maka, dapat disimpulkan bahwa semua indikator dari ketiga variabel X1 (Personal Selling), X2(Advertising) dan Y (Penjualan Polis) adalah valid.
Berdasarkan hasil penelitian yang telah diuraikan untuk menjawab pemasalahan "Pengaruh personal selling dan advertising terhadap penjualan polis asuransi pada PT Jasaraharja Putera Cabang Mataram”.

Dari hasil perhitngan didapat nilai $F_{\text {hitung }} 21.420$ dengan tingkat signifikansi 0,000 yang menunjukkan angka dibawah 0,5, sehingga dapat disimpulkan bahwa terdapat pengaruh positif secara bersamasama variabel independen (Personal selling dan advertising) terhadap variabel dependen (Penjualan polis asuransi) pada PT Jasaraharja Putera Cabang Mataram.

Hasil penelitian in sejalan dengan penelitian yang dilakukan oleh Haryanto, Agus Candra (2008), Dari hasil analisis data menunjukkan besarnya korelasi berganda $\mathrm{R}=0,996$. Hal ini menunjukkan adanya hubungan yang sangat erat dan searah antara Personal Selling dan Advertising secara bersama-sama dengan volume penjualan polis.

Artinya bahwa personal selling berpengaruh positif dan signifikan terhadap keputusan pembelian. Hapsatri,persetyo (2019) Hasil ini menunjukkan jika personal selling yang dilakukan oleh setiap agen asuransi semakin baik dan efektif, maka keputusan pembelian produk asuransi akan semakin meningkat. Sehingga dapat disimpulkan bahwa hipotesis satu yang menyatakan 
bahwa ada pengaruh positif dan signifikan personal selling terhadap terhadap keputusan pembelian secara statistik dapat diterima. Hasil ini berarti jika personal selling yang dilakukan oleh perusahaan semakin baik, efektif dan efisien, maka akan dapat meningkatkan keputusan pembelian produk asuransi pada PT Jasaraharja Putera Cabang Mataram. Dapat disimpulkan bahwa hipotesis satu diterima.

Berdasarkan hasil penelitian yang telah diuraikan untuk menjawab pemasalahan "Bagaimana tingkat pengaruh dari personal selling dan advertising terhadap penjualan polis asuransi secara secara parsial dan simultan pada PT Jasaraharja Putera Cabang Mataram”.

Dilihat dari hasil penelitian tingkat pengaruh antara personal selling dan advertising secara parsial maupun simultan, personal selling lebih berpengaruh dari advertising, secara simultan berpengaruh positif. Pemaparan tentang tingkat pengaruh yaitu, apabila Personal seling dan advertising dibarengi maka akan menghasilkan hasil yang diharapkan, contoh nya apabila melihat iklan asuransi yang sudah sangat menarik tentu saja perlu penjelasan yang detail diperlukan calon nasabah apabila ada pertanyaan-pertanyaan yang ada dari calon nasabah. Jadi dapat disimpulkan bahwa Personal selling dan Advertising berpengaruh pada penjualan polis asuransi pada PT Jasaraharja Putera Cabang Mataram. Adanya temuan penelitian ini diharapkan dapat membantu pihak PT Jasaraharja Putera Cabang Mataram meningkatkan keputusan pembelian pada asuransi Jasaraharja Putera Cabang Mataram.

Hasil penelitian in sejalan dengan penelitian yang dilakukan oleh Hapsatri, persetyo, (2019) yang menjelaskan nilai $\mathrm{t}$ hitung variabel advertising sebesar 5,027, dan nilai tersebut lebih besar daripada nilai t tabel yaitu $(5,027>1,668)$, serta nilai signifikansi sebesar $0,000<0,05$, sehingga hasil keputusannya adalah menerima hipotesis alternatif (Ha). Artinya bahwa advertising berpengaruh positif dan signifikan terhadap keputusan pembelian. Hasil ini menunjukkan jika advertising yang dilakukan oleh setiap agen asuransi semakin baik dan efektif, maka keputusan pembelian produk asuransi akan semakin meningkat. Sehingga dapat disimpulkan bahwa hipotesis dua yang menyatakan bahwa ada pengaruh positif dan signifikan advertising terhadap terhadap keputusan pembelian secara statistik dapat diterima.

Hasil ini menunjukkan bahwa semakin baik advertising yang diukur dengan indikator seperti dapat menimbulkan perhatian, menarik, dapat menimbulkan keinginan, serta menghasilkan suatu tindakan dapat 
menjadi pertimbangan calon nasabah dalam menilai baik atau tidaknya periklanan yang telah dilakukan. Oleh sebab itu, PT Jasaraharja Putera cabang mataram untuk memperhatikan hal-hal tersebut dalam membuat iklan agar dapat meningkatkan keputusan pembelian. Hasil ini telah mendukung hasil penelitian Nugroho (2014), Persetyo, (2019), Anggraini dan Widajati (2015) yang menyatakan advertising berpengaruh positif dan signifikan terhadap keputusan pembelian

\section{PENUTUP}

Personal selling berpengaruh positif dan signifikan terhadap keputusan pembelian. Hal ini dapat dilihat dari personal selling berpengaruh terhadap penjualan polis asuransi pada PT Jasaraharja Putera Cabang Mataram. Hasil ini berarti jika personal selling yang dilakukan oleh perusahaan semakin baik, efektif dan efisien, maka akan dapat meningkatkan keputusan pembelian produk asuransi pada PT Jasaraharja Putera Cabang Mataram. Dapat disimpulkan bahwa hipotesis satu diterima.

Advertising berpengaruh positif dan signifikan terhadap keputusan pembelian. Hal ini dapat dilihat dari nilai t hitung yang lebih besar dari $\mathrm{t}$ tabel dan nilai signifikansi yang lebih kecil dari 0,05. Hasil ini berarti jika advertising atau periklanan yang dilakukan oleh perusahaan semakin menarik dan efektif, maka akan dapat meningkatkan keputusan pembelian produk asuransi pada PT Jasaraharja Putera Cabang Mataram.

\section{DAFTAR PUSTAKA}

Agus Hermawan. 2012. Komunikasi Pemasaran. Jakarta. Erlangga

Anggraini, Dina Yustanti., dan Asih Widajati. 2015. Pengaruh Advertising, Personal Selling Dan Sales Promotion Terhadap Keputusan Pembelian Produk Indihome Pada PT Telkom Indonesia Witel Jatim Selatan (Telkom Blimbing Malang). Jurnal Aplikasi Bisnis, Vol.1 No.1, Hal.7180.

Burhan Bungin. 2011. Metode Kuantitatif. Jakarta. Kencana Prenada Media Group.

Durianto, Brand Equity Ten. 2004. Strategi Pemimpin Pasar. Jakarta. PT Gramedia Pustaka Utama. Jakarta. Ghalia Indonesia.

Hapsari, Persetyo. 2019. Personal Selling, Advertising Dan Asuransi (Studi Pada PT. Prudential Life Assurance Cabang Pandanaran Semarang) Jurnal Ilmiah UNTAG Semarang ISSN: 2302-2752, Vol. 8 No. 2 ,

Husein Umar. 2002. Metode Riset Komunikasi Organisasi. Jakarta. Gramedia Pustaka Utama.

Herman Darmawi. 2002. Manajemen Asuransi. Jakarta. Bumi Aksara.

Ida Royani Tamba. 2015. Pengaruh Personal Selling dan Kualitas Pelayanan Terhadap Keputusan Pembelian Polis Asuransi Jiwasaya 
(Persero) Cabang Pekan Baru. Jurnal Keuangan. Vol.2.No.2

Juwita Mariska Robot. 2015. Analisis Pengaruh Advertising, Personal Selling, Sales Promotion, Publicity dan Word of mouth terhadap Keputusan Pembelian. Jurnal Riset Bisnis dan Manajemen, Vol.3 No.3, Hal: 254-267.

Nugroho, Akhirudin Aji. 2014. Pengaruh Personal Selling dan Advertising Terhadap Pengambilan Keputusan Membeli Polis Asuransi (Studi Kasus Pada PT. Prudential Cabang Lamper Semarang). E-journal Universitas Dian Nuswantoro, Hal.115.

Noviantoro, Bagus., dan Yessy Artanti. 2016. Pengaruh Penjualan Pribadi Dan Citra Merek Terhadap Keputusan Pembelian Polis Asuransi Jiwa Prestigio. Jurnal Bisnis dan Manajemen, Vol.12 No.3, Hal.262-273.

Sandra Moriaty. 2008.Nancy Mitchell. Wiliam Wells. Advertising Edisi Kedelapan. Jakarta. Kencana

Sugiyono. 2016. Metode Penelitian Kuantitatif, Kualitatif dan R\&D, Bandung. PT Alfabet.

Suparwo, Adi., Dwiza Riana., Ratna Deli Sari. 2018. Pelaksanaan Personal Selling Dalam Pengaruhnya Terhadap Keputusan Pembelian Polis Asuransi. Jurnal Ecodemica, Vol.1 No.2, Hal.241-248.

Tamba, Ida Royani., dan Rizikna. 2015. Pengaruh Pesonal Selling dan Kualitas Pelayanan Terhadap Keputusan Pembelian Polis Asuransi Jiwa PT. Asuransi Jiwasaya (Persero) Cabang Pekanbaru. JOM FISIP, Vol.2 No.2, Hal.1-13.
Zuliatin. 2016. Pengaruh Personal Selling, Direct Selling, dan Hubungan Masyarakat Terhadap Keputusan Nasabah, Studi Kasus Pada BMT UGE Sidogiri KCP Kanigoro Blitar. Jurnal Perbankan, Vol. 03.No.1 Oktober 